\title{
The Integration Model of the Development of Student Religious Character Education Based on Integrative Morals in Higher Education
}

\author{
Rahmat Nur ${ }^{1)}$, Suardi ${ }^{2)}$, Nursalam ${ }^{3)}$, Hasnah Kanji ${ }^{4)}$ \\ Sociology Education, Faculty of Teacher Training and Education, University of Lambung Mangkurat, \\ Indonesia ${ }^{1)}$ \\ Sociology Education Study Program, Teacher Training and Education Faculty, Muhammadiyah \\ University of Makassar, Jl. Sultan Alauddin No.259, Makassar, Indonesia 90221 2,3) \\ Primary Education Master Program, Muhammadiyah University of Makassar, Jl. Sultan Alauddin \\ No.259, Makassar, Indonesia 90221 4) \\ rahmat.nur@ulm.ac.id ${ }^{1)}$, suardi@unismuh.ac.id ${ }^{2)}$, nursalam@unismuh.ac.id ${ }^{3)}$, \\ hasnahk10071987@gmail.com ${ }^{4)}$
}

\begin{abstract}
The substance problem in this study is the demoralization of the religious character of students, so it requires a more comprehensive model of strengthening character education. The research objective is to produce an integrated model for the development of moral integrative-based religious character education. The research used a mix-method, namely a combination of qualitative methods and quantitative methods. The qualitative research instrument uses the researcher himself as the main instrument while the quantitative instrument uses a validated questionnaire. Research informants, qualitative research using purposive sampling and random sampling techniques for quantitative research. Data collection techniques using interview techniques, observation techniques, questionnaire techniques and documentation techniques. The stages of qualitative data analysis were carried out by starting to reduce data, display data, and verify data. The results of the research on the integration model of the development of religious character education that has been developed at the University of Muhammadiyah Makassar are integrated with the moral integrative, namely knowing, feeling, sinverbal, action, habitus and culture to instill religious character in students in six moral levels starting from moral knowing, moral feeling, moral. sinverbal, moral action, moral habitus and moral culture at the student and academic community level at the University of Muhammadiyah Makassar.
\end{abstract}

Keywords: Character Education, Moral sinverbal, Moral habitus, Moral culture, Students

\begin{abstract}
Abstrak. Masalah substansi pada penelitian ini adalah demoralisasi karakter religius mahasiswa, sehingga membutuhkan suatu model penguatan Pendidikan karakter yang lebih komprehensif. Tujuan penelitian menghasilkan model integrasi pengembangan pendidikan karakter religius berbasis integratif moral. Penelitian menggunakan mix-method yaitu metode kombinasi metode kualitatif dan metode kuantitatif. Instrumen penelitian kualitatif menggunakan peneliti sendiri sebagai instrumen utama sedangkan instrumen kuantitatif menggunakan angket, yang sudah divalidasi. Informan penelitian, penelitian kualitatif menggunakan purposive sampling dan teknik random sampling untuk penelitian kuantitatif. Teknik pengumpulan data menggunakan teknik wawancara, teknik observasi, teknik angket dan teknik dokumentasi. Tahapan analisis data kualitatif dilakukan mulai mereduksi data, mendisplay data, dan melakukan verifikasi data. Hasil penelitian model integrasi pengembangan pendidikan karakter religius yang telah dikembangkan di Universitas Muhammadiyah Makassar terintegrasi dengan integratif moral yaitu knowing, feeling, sinverbal, action, habitus dan culture untuk menanamkan karakter religius kepada mahasiswa dalam enam tingkatan moral mulai dari moral knowing, moral feeling, moral sinverbal, moral action, moral habitus dan moral culture pada level mahasiswa dan civitas akademika Universitas Muhammadiyah Makassar.
\end{abstract}

Kata Kunci: Pendidikan Karakter, Moral sinverbal, Moral habitus, Moral culture, Mahasiswa 


\section{INTRODUCTION}

Integrating the strengthening of character education at the higher education level is very important for students as a form of inculcating student character (Suardi, Nursalam, et al., 2020) which can be integrated with the learning process in higher education (Suardi, Nursalam, et al., 2020) ( Suardi \& Nursalam, 2020) based on character.

In the Strategic Plan of Muhammadiyah University of Makassar CHAPTER III regarding strategic policies and programs, one of the basic strategies is to increase morals or character through the dynamics of Islamic campus life at the University of Muhammadiyah Makassar (Suardi, Nursalam, et al., 2020). Then it is outlined in the program strategy until 2020, namely strengthening character through the process of education for the moral values of Al-Islam and Muhammadiyah (Suardi, Nursalam, et al., 2020). Each study program at the University of Muhammadiyah Makassar integrates character education in the lecture process. One of the character indicators contained in the vision, mission, goals, learning outcomes of the Study Program at the Muhammadiyah University of Makassar is to become a Study Program with Islamic character and more specifically the Al-Islam Kemuhammadiyahan course, character education courses and nuanced of character. All that is done so that students have the values of national character and Islamic values.

The essence of education and learning is not only optimizing knowledge through learning outcomes and optimizing skills through given assignments (Kanji et al., 2018) (Kanji et al., 2018) (Kanji et al., 2018) (Suardi \& Syarifuddin, 2018) ( Suardi, 2017) (Suardi \& Kanji, 2018).

The integration of character education is carried out through the integration of character in planning, implementing and evaluating the learning process or lecture (Suardi, Nursalam, et al., 2020) (Suardi, Nursalam, et al., 2020) (Suardi \& Nursalam, 2020) (Suardi et al. ., 2018) which requires internal and external support from educational institutions (Kanji et al., 2020b), which is collaborative in education management (Suardi, Agustang, et al., 2020), because of the integration of character education (Kanji et al., 2019b) ) (Nursalam et al., 2020) have supporting factors that must be optimized and there are inhibiting factors that must be overcome (Kanji et al., 2020b), so that character education programs need to always be evaluated (Kanji et al., 2019a).

But in reality this is not the case with various studies on poor student behavior such as (1) premarital sex behavior (2) Hedonism Lifestyle (3) student conflicts (4) Anarchist demonstrations (5) smoking on campus (6) using drugs (7) cheating while exams (8) Pregnant outside of marriage (9) stealing 
motorbikes (10) drinking alcoholic beverages (11) littering (Suardi, Nursalam, et al., 2020). Meanwhile, based on the results of observations carried out from 2019-2020 at the Muhammadiyah University campus and interview data and initial documentation from several lecturers, data was obtained from the majority of students who experienced demoralized values of religious character. One of the indicators is the frequent clashes between students, there are pregnant students outside of marriage, students who steal motorbikes, students do drug trafficking and abuse, students drink alcoholic beverages, students litter and smoke students on campus (Suardi, Nursalam, et al. al., 2020).

This shows that character education on the Islamic campus of the Muhammadiyah University of Makassar needs to be improved so that the strengthening of character values within the Muhammadiyah University of Makassar. So far, the character value planting model used is only limited to students having character knowledge (knowing), character feelings (feeling) and character behavior (action) (Lickona, 1991), but it has not touched moral sinverbal, habitus and culture at the individual or student level. group or university level (Kanji et al., 2019b) (Suardi, Nursalam, et al., 2020). This can be developed in academic activities at universities at Muhammadiyah Makassar University so that character education is not only carried out by students but collectively by all the academics of the University of Muhammadiyah Makassar including lecturers and campus leaders Therefore, the development of integrated character education is very important to be carried out based on integrative morals in universities, especially at the University of Muhammadiyah Makassar.

Research on character education development models for students and college students has been conducted by several researchers, such as (Nasrudin et al., 2015) concerning a character education development model based on human imagery, namely the sanctity of the human soul. However, the sanctity of the soul is the same as the moral feeling which does not yet explain knowing, sinverbal, action, habitus, culture. (Rachman et al., 2017) regarding the character education development model based on training, however, the training only focuses more on moral action but has not yet reached moral knowing, feeling, sinverbal, habitus, culture. (Lexi, 2015) examines a character education development model based on socio-cultural values, but the socio-cultural values only exist in the moral habitus and moral culture, not yet touching moral knowing, feeling, sinverbal, action. (Zuchdi et al., 2010) and (Suardi et al., 2019) examined the integrated character education development model in the learning process, but the integration of character with learning in the field of study focuses more on the external aspects of the individual or group has not explained the individual to the group 
(external). ). (Walid, 2011) regarding a character education development model based on ulul albab, namely the integrated education program of higher education boarding schools, but it has not focused more on the external aspects of individuals or groups, has not explained the individual to the group (external). In general, all research results have not studied in substance about moral knowing, feeling, sinverbal, habitus and culture (Nursalam et al., 2020). Meanwhile, the research that will be carried out focuses on a character education development model that is integrated with moral knowing, feeling, sinverbal, action, habitus and culture which is more comprehensive (Kanji et al., 2020a).

\section{RESEARCH METHODS}

This research uses a concurrent embedded mix-method method, namely a combination of qualitative and quantitative methods. Research procedures by combining qualitative and quantitative data in order to obtain data from a more comprehensive analysis based on problems (Creswell, 2013). The reason for using the concurrent embedded mix-method method is because (i) the formulation of the problem in different studies, (ii) using several different methods, (iii) balancing in-depth interview data, observation data and document data obtained with questionnaire data, (iv) complement the qualitative data with quantitative data so that the research results are more comprehensive. (v) confirm the qualitative data result information with quantitative data so that the research results are more valid (Sugiyono, 2011). The qualitative research instrument uses the researcher himself as the main instrument, namely as an observer and researcher and uses an instrument of interview guide sheets, observation guideline sheets, documentary note guideline sheets, a camera for photos or videos and using a recording device. While the quantitative instrument uses a questionnaire, which has been validated by the research informants, qualitative research uses purposive sampling (qualitative) while the determination of the research sample uses the proportional stratified sampling technique. Researchers used data from interviews, questionnaire results and observation data as primary data, while document data was used as secondary data related to research. Collecting data using (1) questionnaires through distributing questionnaires to all respondents, (2) observation through distance observation, limited observation, and full observation, (3) in-depth interviews through guided interviews previously prepared by researchers based on the formulation of research problems (4) documentation through searching documents related to research such as photos, regulations and policies. Researchers performed data analysis, namely data reduction in the first stage, displaying data in the second stage and verification of data in the third stage (Sugiyono, 2011), then analyzing quantitative 
data by testing the validity of the questionnaire used (valid).

\section{DISCUSSION}

Religious (religious) is a way of thinking, behaving and behaving that reflects faith in God Almighty, which is manifested in the behavior of carrying out religious teachings and beliefs, respecting religious differences, upholding a tolerant attitude towards the implementation of religious worship and other beliefs, and life. harmony and peace with followers of other religions (Suardi, Nursalam, et al., 2020)

Development of moral knowledge based on the results of research at the University of Muhammadiyah Makassar, students have moral knowledge with six indicators (Lickona, 1991) of the value of religious character. The following is a table of the percentage of students who have moral knowing, from 50 respondents consisting of students.

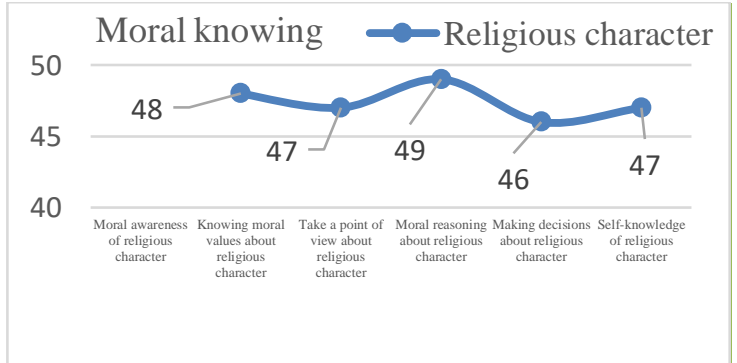

Diagram 1. Moral knowing students about the value of religious characters.

Development of moral feelings based on the results of research at the University of Muhammadiyah Makassar, students have moral feelings with six indicators (Lickona, 1991) of the value of students' religious character. The following table shows the percentage of students who have moral feeling from 50 respondents consisting of students and lecturers.

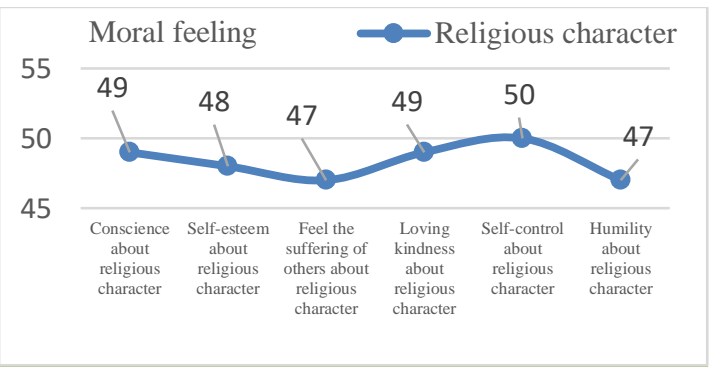

Diagram 2. Students' moral feelings towards religious character values.

The development of moral symbols and words based on the results of research at the University of Muhammadiyah Makassar, students have symbols and moral words with three indicators (Kanji et al., 2019b) (Nursalam et al., 2020) the value of student religious character. The following is a table of the percentage of students who have synverbal moral from 50 respondents consisting of students and lecturers.

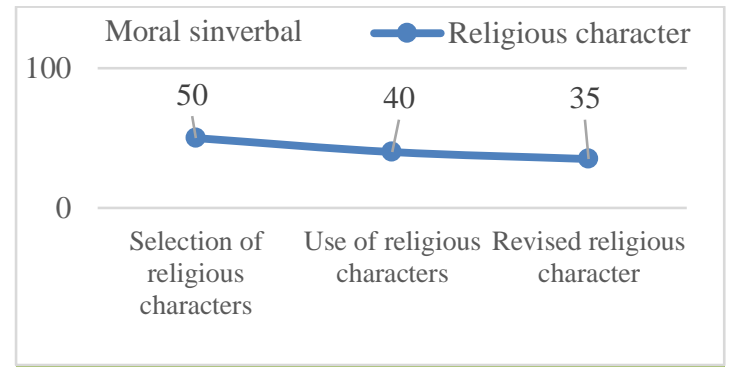

Diagram 3. Student's sinverbal moral towards religious character values.

Development of moral behavior based on the results of research at the University of 
Muhammadiyah Makassar, students have moral action with three indicators (Lickona, 1991) of the value of religious character. The following is a table of the percentage of students who have moral action from 50 respondents consisting of students and lecturers.

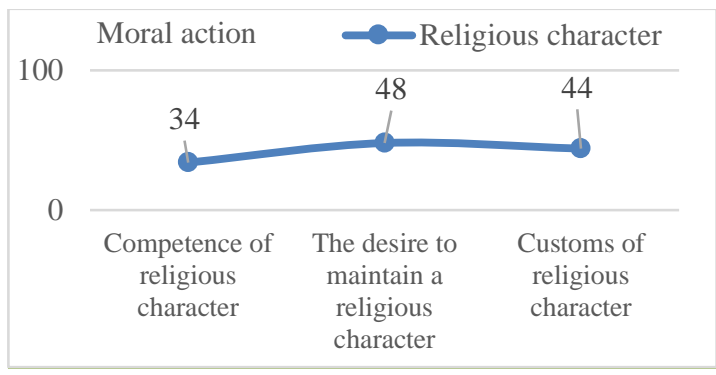

Diagram 4. Moral action of students on values of religious character.

Development of moral habits based on the results of research at the University of Muhammadiyah Makassar, students have moral habits with three indicators (Kanji et al., 2019b) (Nursalam et al., 2020) the value of religious character. The following table shows the percentage of students who have a moral habitus of 50 respondents consisting of students.

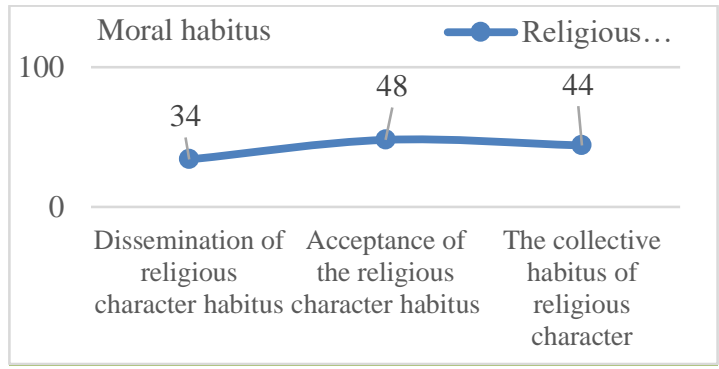

Diagram 5. Moral habitus of student $d$ on religious character values.

The development of a moral culture based on the results of research at the
University of Muhammadiyah Makassar still needs to be improved to have a moral culture with three indicators (Kanji et al., 2019b) (Nursalam et al., 2020) the value of religious character. The following is a table of the percentage of students who have a moral culture from 50 respondents consisting of students.

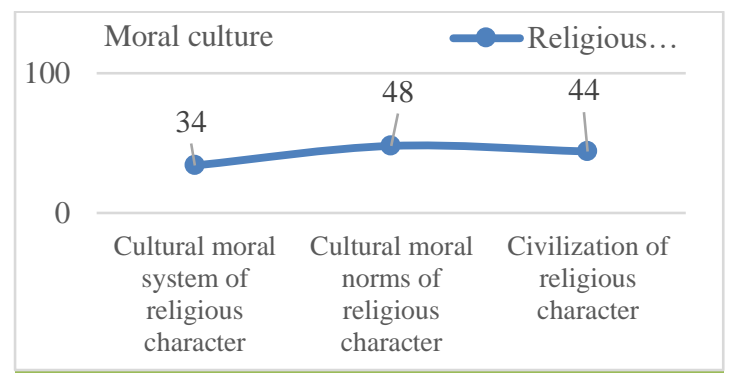

Diagram 6. Students' moral culture towards religious character values.

\section{Integration of Strengthening Religious} Character Education with Moral Knowing.

Strengthening religious character education (Suardi, Nursalam, et al., 2020) can be formed through the integration of moral knowing with various stages. Starting from the first stage of moral awareness (moral awareness, the second stage of knowing moral values), the third stage is taking perspective taking, the fourth stage is moral reasoning, the fifth stage is decision making. and the sixth stage of self-knowledge (self-knowledge (Lickona, 1991).

1. Moral awareness about religious character is that students use their intelligence to judge a situation to suit religious moral values. The educational activities of the 
University of Muhammadiyah Makassar are in accordance with religious morals because (1) Muhammadiyah University of Makassar, which is an Islamic-based educational institution that reflects faith in God Almighty, continues to strive to carry out the commands of Allah SWT and stay away from all prohibitions from all academics and more specifically students according to the teachings of Islam. (2) Respecting religious differences between students even though Muhammadiyah Makassar University is an Islamic campus but does not close itself to accepting students who have religions other than Islam such as Christianity, (3) Lecturers and students who are Muslim equally uphold a tolerant attitude towards the implementation of worship religions and other beliefs, as well as Christian students uphold a tolerant attitude towards the implementation of Muslim student worship. (4) Students of the University of Muhammadiyah Makassar, who are predominantly Muslim, live in harmony with Christian students. All of these indicators are the actualization of the values of religious character and are in accordance with the values and social norms prevailing in society. Religious moral knowledge is instilled through educational process activities, including academic, coacademic, extra-academic and nonacademic activities. Religious moral ownership means that students and the academic community can maintain a relationship with God, maintain relationships with fellow humans and maintain relationships with the universe (Suardi, Nursalam, et al., 2020)

2. Know moral values about religious character is that students know the various moral values that exist in their environment that are related to religious morals. Religious moral values that exist around the social environment of students related to religious morals at the Muhammadiyah University of Makassar are love of peace, tolerance, respect for differences in religion and belief, steadfastness, confidence, cooperation between followers of religions and beliefs, anti-violence and violence, friendship, sincerity, not imposing your will, loving the environment, and protecting the small and marginalized (Suardi, Nursalam, et al., 2020).

3. Take a standpoint of religious character is the ability of students to take the point of view of others, such as feeling what other people feel, and imagining what other people might think and react to something related to religion, such as students feel and think like other people who believe in Allah SWT, respect religious differences, uphold a tolerant attitude and live in harmony with students of different religions (Suardi, Nursalam, et al., 2020). 
4. Moral reasoning about religious character is a student's understanding of what it means to be moral and why every student must have religious morals, so that every student must have a basic knowledge of every religious moral action that is carried out such as why every student must believe in Allah SWT, respect religious differences , upholding a tolerant attitude and living in harmony with students of different religions (Suardi, Nursalam, et al., 2020).

5. Decision making about religious character is the ability of students to make decisions and actions in dealing with problems related to religion. Students must be able to solve various problems guided by religious moral values such as overcoming obstacles, obstacles or temptations from outside and from within not to believe in Allah SWT, respecting religious differences, upholding tolerant attitudes and living in harmony with students of different religions, under conditions that every student must be able to make the decision to exercise faith in Allah SWT, respect religious differences, uphold a tolerant attitude and live in harmony with students of different religions even under any circumstances (Suardi, Nursalam, et al., 2020).

6. Self-knowledge of religious character is the ability of students to know and evaluate their own behavior related to religion. Students are able to know the strengths and weaknesses of each student related to religious morals such as believing in Allah SWT, respecting religious differences, upholding a tolerant attitude and living in harmony with students of different religions. Their weaknesses are continuously evaluated so that each student has a more religious personality (Suardi, Nursalam, et al., 2020).

\section{Integration of Strengthening Religious Character Education with Moral Feeling.}

Religious character (religious) can be formed through the integration of moral feelings with various stages. Starting from the first stage of conscience (conscience), the second stage of self-esteem (self-esteem), the third stage of feeling the suffering of others (empathy), the fourth stage of loving the good, the fifth stage of self-control and the sixth stage. humility (Lickona, 1991).

1. Conscience about religious character is the feeling of students to be obliged to carry out what is right, such as believing in Allah SWT, respecting religious differences, upholding tolerant attitudes and living in harmony with students of different religions and staying away from wrong (Suardi, Nursalam, et al., 2020).

2. Self-esteem about religious character, is the correct measure that exists in students so that they do not allow others to abuse them. Measuring the value of believing in Allah SWT, respecting religious differences, upholding a tolerant attitude and living in 
harmony with students of different religions are suggestions that must be implemented by every student, so that anyone should not prohibit believing in Allah SWT, prohibit respect for religious differences, prohibit supporting attitudes tolerant and live in harmony with students of different religions and still maintain these moral values (Suardi, Nursalam, et al., 2020).

3. Feel the suffering of others about religious character is the ability of students to recognize and understand the situation of others. Students must be able to recognize students who believe in Allah SWT, respect religious differences, uphold a tolerant attitude and live in harmony with students of different religions and understand that they can understand the situation of other students who believe in Allah SWT, respect religious differences, uphold tolerance and live in harmony with students of different religions (Suardi, Nursalam, et al., 2020).

4. Loving kindness about religious character is the ability of students to always like and love good things. Believing in Allah SWT, respecting religious differences, upholding a tolerant attitude and living in harmony with students of different religions are good things, so that the advice to believe in Allah SWT, respect religious differences, uphold tolerance and live in harmony with students of different religions can make students love good things (Suardi, Nursalam, et al., 2020).

5. Self-control about religious character is the ability of students to behave in accordance with ethics, morals, morals or applicable rules in accordance with applicable ethics, morals, morals or rules related to religion. Muhammadiyah Makassar University students strive to always have faith in Allah SWT, respect religious differences, uphold a tolerant attitude and live in harmony with students of different religions in accordance with applicable ethics, morals, morals or regulations (Suardi, Nursalam, et al., 2020) at the University of Muhammadiyah Makassar Campus.

6. Humility about religious character is the ability of students to always be open to their own limitations and correct mistakes that have been made related to religion, so that each student must be open to their limitations and accept criticism from others to become a more religious person who believes in Allah SWT, respects religious differences, upholds a tolerant attitude and lives in harmony with students of different religions (Suardi, Nursalam, et al., 2020).

\section{Integration of Strengthening Religious Character Education with Sinverbal Morals}

Religious character (religious) can be formed through the integration of moral sinverbal in various stages. Starting from the 
first stage of selection (selection), the stage of use (use), and the third stage of revision (Kanji et al., 2019b) (Nursalam et al., 2020).

1. Religious character selection is the attitude and action of selecting every word that will be spoken and selecting every symbol that will be used in relation to religion in interacting with other people with the moral knowledge and moral feelings they have to select words and Moral symbols such as students selecting words and symbols that show these students believe in Allah SWT, selecting words and symbols respecting religious differences, selecting words and symbols that support tolerance and selecting words and symbols that show life get along well with students of different religions (Suardi, Nursalam, et al., 2020).

2. Use of religious characters is the attitude and actions of using religious moral words and symbols which are the result of selecting moral knowledge and moral feelings to interact with others, such as students using words and symbols that indicate the student having faith in Allah SWT, words and symbols respecting religious differences, words and symbols support tolerance and words and symbols that show harmonious life with students of different religions (Suardi, Nursalam, et al., 2020).

3. Revision of religious characters is the attitude and action of correcting the spoken words and symbols that are used to always use words and moral symbols that show the student believes in Allah SWT, words and symbols of respect. different religions, words and symbols support tolerant attitudes and words and symbols that show a harmonious life with students of different religions (Suardi, Nursalam, et al., 2020).

\section{Integration of Strengthening Religious Character Education with Moral Action.}

Religious character (religious) can be formed through the integration of moral action with various stages. Starting from the first stage of competence (competence), the second stage of desire (will), and the third stage of habits (habit) (Lickona, 1991).

1. Competence of religious character is the ability of students to change their moral thoughts about religion and their moral feelings about religion to become good moral actions in the form of carrying out their religious teachings such as believing in Allah SWT, respecting religious differences, uphold a tolerant attitude and live in harmony with students of different religions (Suardi, Nursalam, et al., 2020).

2. The desire to maintain a religious character is the ability of students to have a desire to maintain moral thoughts and moral feelings and to withstand various pressures and temptations of abnormal behavior. Students of the University of Muhammadiyah Makassar continue to believe in Allah SWT, respect religious differences, uphold 
a tolerant attitude and live in harmony with students of different religions, this is done to maintain religious knowledge and religious feelings that these activities are good things and distance themselves from various temptations comes from internal aspects (students themselves) and external aspects (other people) not to believe in Allah SWT, not to respect religious differences, not to support tolerance and to live in harmony with students of different religions (Suardi, Nursalam, et al., 2020 ).

3. Customs of religious character is the ability of students to familiarize themselves with religious thoughts, religious feelings and apply them in religious actions. Believing in Allah SWT is an obligation, respecting religious differences is a must, supporting a tolerant attitude and living in harmony with students of different religions becomes a meaningful routine for students so that repetitive behavior eventually becomes a habit or habit with character (Suardi, Nursalam , et al., 2020).

\section{Integration of Strengthening Religious} Character Education with Moral Habitus.

The religious character (religious) can be formed through the integration of moral habitus with various stages. Starting from the first stage of habitus dissemination, the second stage of habitus acceptance, and the third stage of collective habitus (Kanji et al., 2019b) (Nursalam et al., 2020).
1. Dissemination of religious character habitus is the attitude and action of spreading moral knowledge, moral feelings, words and the use of religious moral symbols to others. The academic community, lecturers and students spread religious morality to students to believe in Allah SWT, respect religious differences, uphold tolerance and live in harmony with students of different religions (Suardi, Nursalam, et al., 2020).

2. Acceptance of the habitus of religious character is the attitude and action of accepting moral knowledge, moral feelings, words and the use of moral symbols obtained from interactions with others. Students open themselves to religious morals such as believing in Allah SWT, respecting religious differences, upholding tolerant attitudes, living in harmony with students of different religions and various other forms of religious morality (Suardi, Nursalam, et al., 2020).

3. The collective habitus of religious characters are attitudes and actions carried out in accordance with the habits of community groups such as moral knowledge, moral feelings, words and the use of moral symbols that are owned related to religious morals. Students and lecturers collectively believe in Allah SWT, respect religious differences, uphold a tolerant attitude, live in harmony with 
students of different religions (Suardi, Nursalam, et al., 2020).

\section{Integration of Strengthening Religious}

Character Education with Moral

\section{Culture.}

Religious character (religious) can be formed through the integration of moral culture with various stages. Starting from the first stage of cultural moral systems, the second stage of cultural moral norms, and the third stage of civilization (Kanji et al., 2019b) (Nursalam et al., 2020).

1. 1.a cultural moral system of religious characters (cultural moral system of religious character) attitudes and actions of community groups in accordance with moral knowledge, moral feelings, words and use of moral symbols, moral actions and moral habits in everyday life which includes all aspects life such as religion, education, politics, economics and others with religious moral nuances, namely all the academics of the Muhammadiyah University of Makassar believe in Allah SWT, respect religious differences, uphold tolerance, live in harmony with students of different religions (Suardi, Nursalam, et al. al., 2020).

2. Cultural moral norms of religious character (cultural moral norms of religious character) attitudes and actions of community groups that make moral knowledge, moral feelings, words and use of moral symbols, moral actions and moral habitus into a norm or rule that is the guide of community groups and have social sanctions for those who violate religious morals, so that academics who violate religious morals such as not believing in Allah SWT, disrespecting religious differences, not supporting tolerant attitudes, not living in harmony with students of different religions will get social sanctions or academic sanctions without with the exception of both leaders, lecturers, students and staff (Suardi, Nursalam, et al., 2020).

3. Civilization of religious character (civilization of religious character) attitudes and actions of community groups that make moral knowledge, moral feelings, words and use of moral symbols, moral actions and religious moral habitus, namely believing in Allah SWT, respecting religious differences, upholding tolerant attitudes, Living in harmony with students of different religions as the identity of the Muhammadiyah University of Makassar through the crystallization process of religious moral values which is the benchmark for the behavior of the Muhammadiyah University of Makassar academic community (Suardi, Nursalam, et al., 2020). 


\section{CONCLUSION}

The integrated model for the development of religious character education that has been developed at the University of Muhammadiyah Makassar is integrated with moral integrations, namely knowing, feeling, sinverbal, action, habitus and culture to instill religious character in students in six moral levels starting from moral knowing, moral feeling, moral sinverbal, moral action, moral habitus and moral culture at the level of students and the academic community of Muhammadiyah University of Makassar.

\section{REFERENCES}

[1] Agustang, A., \& Sahabuddin, J. (2020, October). MODEL KOLABORASI SOSIAL PENDIDIKAN KARAKTER DI SEKOLAH SWASTA KECAMATAN BISSAPPU KABUPATEN BANTAENG. In PROSIDING SEMINAR DAN DISKUSI PENDIDIKAN DASAR.

[2] Agustang, A. (2020). The Symbolic Violence Towards Private School Students Through The Frame Stereotype In Bantaeng District Of Indonesia. Prosiding ICoISSE, 1(1), 578-588.

[3] Agustang, A. (2020). Symbolic Violence towards Students in the Context of the Existence of the Stereotypical Frames of Lecturers and Students in the Higher Education System in Indonesia. PalArch's Journal of Archaeology of Egypt/Egyptology, 17(2), 249-258.

[4] Agustang, A., Suardi, I. A. M., Mutiara, I. A., \& Ramlan, H. (2020). SOCIAL PRENEUR DALAM PENANGGULANGAN KEMISKINAN DI KECAMATAN BISSAPPU KABUPATEN BANTAENG. Martabe: Jurnal Pengabdian Kepada Masyarakat, 3(2), 331-342.

[5] Agustang, A., \& Asrifan, A. (2021). PERAN PENDIDIKAN DALAM MEMBANGUN KARAKTER BANGSA.
[6] Creswell, W. J. (2013). Research Design Pendekatan Kualitatif, Kuantitatif dan Mixed. Pustaka Pelajar.

[7] Hasnah, K., Amin, B., Syakur, A., \& Suardi, S. (2018). Peningkatan Hasilbelajar Bahasa Indonesia Melalui Model Pembelajaran Kooperatif Tipe Numbered Heads Together. JRPD (Jurnal Riset Pendidikan Dasar), 1(1), 25-33.

[8] Hasnah, K. (2020). PENGUATAN PENDIDIKAN KARAKTER: BERBASIS INTEGRATIF MORAL DI PERGURUAN TINGGI (Vol. 1). CV. AA. RIZKY.

[9] Kanji, H., Nursalam, N., Nawir, M., \& Suardi, S. (2019). Evaluasi Integrasi Pendidikan Karakter dalam Pembelajaran Ilmu Pengetahuan Sosial di Sekolah Dasar. JED (Journal of Etika Demokrasi), 4(2).

[10] Kanji, H., Nursalam, N., Nawir, M., \& Suardi, S. (2020). INTEGRATION OF SOCIAL CARE CHARACTERS AND MORAL INTEGRATIF ON SOCIAL SCIENCE LESSONS IN ELEMENTARY SCHOOL. AL-ISHLAH: Jurnal Pendidikan, 12(2), 413-427.

[11] Kanji, H., Nursalam, N., Nawir, M., \& Suardi, S. (2019). MODEL INTEGRASI PENDIDIKAN KARAKTER DALAM PEMBELAJARAN ILMU PENGETAHUAN SOSIAL DI SEKOLAH DASAR. JURNAL PENDIDIKAN DASAR PERKHASA: Jurnal Penelitian Pendidikan Dasar, 5(2), 104-115.

[12] Kanji, H., Nursalam, N., Nawir, M., \& Suardi, S. (2020). Supporting and Inhibiting Factors of Character Education in Learning Social Studies at Primary Schools. JED (Journal of Etika Demokrasi), 5(1), 1-14.

[13] Lexi, A. Lo. (2015). Pengembangan model pendidikan karakter berbasis nilai sosiokultural pada siswa SMA di Minahasa. Mimbar: Jurnal Sosial Dan Pembangunan, 31(2), 319-327. https://ejournal.unisba.ac.id/index.php/mimb ar/article/download/1416/1112

[14] Lickona, T. (1991). Educating for Character: How Our Schools Can Teach Respect and Responsibility - Thomas Lickona - Google 
Buku.

[15] Nasrudin, Herdiana, I., \& Nazudi, N. (2015). PENGEMBANGAN

PENDIDIKAN BERDASARKAN SIFAT FITRAH MANUSIA. Jurnal Pendidikan Karakter, $O(3)$, 264-271. https://doi.org/10.21831/jpk.v0i3.5631

[16] Nursalam, Nawir, M., Suardi, \& Kanji, H. (2020). Model Pendidikan Karakter Pada Mata Pelajaran Ilmu Pengetahuan Sosial Di Sekolah Dasar (Vol. 1). CV. AA. RIZKY. https://books.google.co.id/books?hl=id\&lr= \&id=8tUKEAAAQBAJ\&oi=fnd\&pg=PA63 $\& d q=$ buku+suardi+nursalam+pendidikan+ka rakter\&ots $=1 \mathrm{~A}-$

g2fQs4\&sig=zVhj4kYePdGJVf09G419nxFsH4\&redir_esc=y\#v=onepage \&q=buku suardi nursalam pendidikan karakter\&f=false

[17] Nursalam, N., Suardi, S., Syarifuddin, S. Mutiara, I. A., \& Herdianty, R. (2020). PEMBERDAYAAN MASYARAKAT DESA MELALUI LITERASI DIGITAL BERBASIS CR CODE DI DESA BONTO JAI KECAMATAN BISSAPPU KABUPATEN BANTAENG. Jurnal Pengabdian Pada Masyarakat MEMBANGUN NEGERI, 4(2), 228-238.

[18] Manda, D. (2020). Sexual Abuse (A Study of Child Sexual Abuse in Poleang District Bombana Regency). PalArch's Journal of Archaeology of Egypt/Egyptology,17(2), 232-240.

[19] Rachman, M., Masrukhi, M., Munandar, A., \& Suhardiyanto, A. (2017). Pengembangan Model Manajemen Pelatihan Dan Pengembangan Pendidikan Karakter Berlokus Padepokan Karakter. Refleksi Edukatika: Jurnal Ilmiah Kependidikan, $8(1)$, $16-26$. https://doi.org/10.24176/re.v8i1.1779

[20] Suardi, S. (2017). Peningkatan Hasil Belajar Sosiologi Pokok Bahasan Interaksi Sosial Melalui Metode Diskusi pada Siswa Kelas X MA. Muhammadiyah Panaikang Kacamatan Bissappu Kabupten Bantaeng. JED (Journal of Etika Demokrasi), 2(1).

[21] Suardi, \& Nursalam. (2020). Penerapan Model Pembelajaran Saintifik Approach
Berbasis Media Classroom Indonesian Journal of Sociology, Education, and Development. Indonesian Journal of Sociology, Education, and Devolopment, 2(2), 88-97. http://ijsed.ap3si.org/index.php/journal/articl e/view/vol2iss2_2020_2suardi

[22] Suardi, S., Herdiansyah, H., Ramlan, H., \& Mutiara, I. A. (2019). Implementasi Pendidikan Karakter Melalui Mata Pelajaran Pendidikan Kewarganegaraan di SMA Jaya Negara Makassar. JED (Journal of Etika Demokrasi), 4(1).

[23] Suardi, S., \& Kanji, H. (2018). Lecture Model of Student Transfer Discussion Method to Increase Student's Activeness and Learning Outcomes. Journal of Educational Science and Technology (EST), 4(1), 48-54.

[24] Suardi, S., Megawati, M., \& Kanji, H. (2018). Pendidikan Karakter di Sekolah (Studi Penyimpangan Siswa di Mts Muhammadiyah Tallo). JED (Journal of Etika Demokrasi), 3(1).

[25] Suardi, S. (2018). Penerapan Model Pembelajaran Saintifik Approacd Berbasis Media Pembelajaran Kearifan Lokal pada Mata Kuliah Dasar-Dasar Sosiologi dalam Membangun Karakter dan Meningkatkan Hasil Belajar Mahasiswa Pendidikan Sosiologi Universitas Muhammadiyah Makassar. JED (Journal of Etika Demokrasi), 3(2).

[26] Sugiyono. (2011). Metode penelitian kombinasi (mixed methods). Alfabeta.

[27] Walid, M. (2011). Model Pendidikan Karakter Di Perguruan Tinggi Agama Islam (Studi tentang Pendidikan Karakter Berbasis Ulul albab di Universitas Islam Negeri Maulana Malik Ibrahim Malang). Jurnal ELQUDWAH, 1(5). http://ejournal.uinmalang.ac.id/index.php/lemlit/article/view/19 43

[28] Zuchdi, D., Kun Prasetya, Z., \& Siasah, D. M. (2010). Pengembangan Model Pendidikan Karakter Terintegrasi Dalam Pembelajaran Bidang Studi Di Sekolah Dasar. In journal.uny.ac.id.

https://journal.uny.ac.id/index.php/cp/article/ download/224/143 